\title{
Accuracy of Satellite-Based Solar Data to Estimate Solar Energy Potential for Hatay Province, Turkey
}

\author{
Ahmet IRVEM* ${ }^{*}$ Mustafa OZBULDU \\ Mustafa Kemal University Faculty of Agriculture, Biosystems Engineering Department, Hatay
}

\begin{abstract}
Solar radiation data is important parameter to estimate solar energy which is a major renewable energy in terms of sustainable resources. Accurate spatial and temporal distribution of solar radiation is required not only to estimate solar energy but also hydrological, meteorological and climatological studies. General objective of the study is to examine accuracy of freely available Climate Forecast System Reanalysis (CFSR) solar radiation data against ground observation data based on monthly and yearly averages over the Hatay province in Turkey. The CFSR dataset including 25 daily solar radiation measurement points was evaluated against 12 ground stations for 21 -year period (1985 - 2006). Statistical results showed that most correlations in monthly basis data were weakly correlated except October $\left(\mathrm{R}^{2}=0.73\right)$. According to results of Bias, CFSR monthly averaged solar energy was over estimated for all months. Also, CFSR annual solar energy $28 \%$ higher than ground-based observed solar energy with $\mathrm{R}^{2}=0.76$. Annual CFSR solar energy found between 5.2 and $5.6 \mathrm{kWh} \mathrm{m}^{-2} \mathrm{day}^{-1}$. Annual ground-based solar energy ranged from 3.9 to $4.2 \mathrm{kWh} \mathrm{m}^{-2} \mathrm{day}^{-1}$. The results show that the use of the CFSR dataset is not advisable in the absence of annual and monthly average ground-based solar radiation measurement values. Estimated CFSR data has need to be improved and accuracy of CFSR data must be tested for other regions in Turkey. We recommend that another source of satellite-based data have to be tested by comparing with ground-based data.
\end{abstract}

Keywords: CFSR dataset, Solar radiation, Hatay, GEPA, ILWIS.

\section{Hatay İli için Güneş Enerjisi Potansiyelini Tahmin Etmede Uydu Tabanlı Solar Verilerinin Doğruluğu}

\begin{abstract}
$\ddot{O} \mathbf{z}$
Güneş radyasyon verileri, sürdürülebilir kaynaklar açısından önemli bir yenilenebilir enerji olan güneş enerjisini tahmin etmek için önemli bir parametredir. Güneş radyasyonunun alansal ve zamansal dağılımının, doğruluğu sadece güneş enerjisi tahmini için değil, ayrıca hidrolojik, meteorolojik ve iklimsel çalışmalar için de gereklidir. Çalışmanın genel amacı, Türkiye'nin Hatay ilindeki aylık ve yıllık ortalamalara dayanan yer gözlem verilerine karşı ücretsiz olarak elde edilebilen CFSR solar radyasyon verilerinin doğruluğunu incelemektir. 21 ylllık dönem için 25 adet günlük güneş radyasyonu ölçüm noktalarını içeren CFSR veri seti, 12 yer istasyonuna karşı değerlendirilmiştir (1985- 2006). İstatistiksel sonuçlar, aylık bazda ki verilerin çoğunun Ekim ayı dişında aralarında zayıf ilişki olduğunu göstermiştir $\left(\mathrm{R}^{2}=0.73\right)$. Bias sonuçlarına göre, $\mathrm{CFSR}$ aylık ortalama güneş enerjisi tüm aylar için tahmin edilmiştir. Ayrıca, CFSR yıllık güneş enerjisi $\mathrm{R}^{2}=0.76$ ile yer esaslı gözlemlenen güneş enerjisinden $\% 28$ daha yüksek olduğu belirlenmiştir. Yıllık CFSR güneş enerjisi, 5.2 ile $5.6 \mathrm{kWh} \mathrm{m}^{-2} \mathrm{gün}^{-1}$ arasında bulunmuştur. Yıllık yer esaslı güneş enerjisi ise 3.9 ile $4.2 \mathrm{kWh} \mathrm{m}^{-2} \mathrm{gün}^{-1}$ arasında değiş̧mektedir. Sonuçlar, aylık ve yıllık ortalama olarak ölçülen yer esaslı güneş radyasyon değerlerinin bulunmaması durumunda, CFSR veri setinin kullanılmasının kabul edilemez olduğunu göstermiştir. CFSR verilerinin iyileştirilmesine ihtiyaç olduğu ve Türkiye'de diğer bölgeler için CFSR verilerinin doğruluğunun test edilmesinin gerekli olduğu sonucuna varılmıştır. Yer istasyon esaslı güneş radyasyon verilerinin, CFSR'den farklı uydu esaslı veri kaynakları kullanılarak doğruluğunun araştırılması önerilmektedir.
\end{abstract}

Anahtar Kelimeler: CFSR veri seti, Güneş radyasyonu, Hatay, GEPA, ILWIS.

\footnotetext{
"Sorumlu yazar: airvem@mku.edu.tr

Geliş Tarihi: 31.05.2018, Kabul Tarihi: 14.11.2018
} 


\section{Introduction}

Solar radiation data is important parameter to estimate solar energy which is major renewable energy in terms of environmentally sustainable resources. Accurate spatial and temporal distribution of solar radiation is required not only to estimate solar energy but also hydrological, meteorological and climatological studies. In developing countries, number of observation stations for solar radiation is sparse and unevenly distributed. Satellite-based data have the great potential for solution of this problem. However, comparative evaluation of gauge based, and satellite-based data is necessary to test accuracy of data. There are mainly three sources of solar radiation observations, including traditional groundbased measurement from surface network, ground-based radar and satellite-based estimations. Recently, satellite-based data have become readily available from different sources. A few studies in the literatures have been done to validate satellite-based data comparing rainfall [1-2], wind speed [3]. Also, some aspects of climate variability in the CFSR have been documented in a few previous studies, including oceanic variability [4], surface climate and variability [5], tropospheric variability [6] precipitation frequency and intensity characteristics [7], and local drought features [8].

Lekula et al., (2018) studied to forecast daily precipitation from FEWS-RFE 11 km, TRMM3B42 27 km, CMOPRH $27 \mathrm{~km}$ and CMORPH $\sim 8 \mathrm{~km}$ were evaluated against daily precipitation recordings in Central Kalahari Basin during a five-year period. The aim of the study was to evaluate the daily precipitation detection capabilities of the four satellite-based precipitation estimates algorithms, analyze the spatiotemporal variability of rainfall in the basin and perform bias-correction of the four satellite-based precipitation estimates. The results showed that the importance of validating daily satellite-based precipitation estimates because of having different precipitation detection capabilities in the basin. The FEWS-RFE 11 km showed the best performance providing better results of descriptive and categorical statistics than the other three satellite-based precipitation estimates [2].

Li et al., (2018) were used Tropical Rainfall Measuring Mission (TRMM) precipitation product data for hydrologic simulations in the area of the Tiaoxi basin. It was found that the TRMM precipitation data showed an outstanding performance at the monthly and yearly scales, fitting well with surface observation-based frequency precipitation distributions. They expressed that post-real-time 3B42 can be a precious tool of hydrologic modeling, water balance analysis, and basin water resource management, particularly in developing countries or at remote locations in which measuring of precipitation are insufficient [9].

El Afandi (2014) was used Climate Forecast System Reanalysis (CFSR) to assess meteorological data such as maximum, minimum and average temperature at two meters, dew point temperature at two meters, mean atmospheric pressure at sea level, relative humidity and total cloud cover, which data obtained from 23 stations in Egypt. He explained that the results show good agreement between CFSR and ground station measurements. Most correlations were highly correlated except very few stations [10].

Malvern and Maurice (2018) were compared rainfall and temperature data obtained from an automated weather station and Mesa satellite earth station in Zimbabwe. All of the comparisons were based on daily rainfall totals and maximum temperatures, as the season of 2016/2017 had significant rains and marked maximum temperatures. They found that there is a marked similarity in temperature and rainfall trend patterns of the two, with ground-based data leading satellite data by a marked 2-4 days difference. However, the regression analysis for both temperature and rainfall gave $\mathrm{R}^{2}$ values of 0.0241 and 0.0016 respectively. They observed that satellite data was for areal data whereas ground based gave point data. Ground data considered topographical differences which the remotely sensed data did not hence the differences. As a result, the comparisons for the two data sets can be restricted to trend validations and not calibrations [11].

Khaled and El Afandi (2014) compared the CFSR solar data against ground-based observation in The Middle East and North Africa. They used 13 ground stations over Egypt, 3 stations in North West Africa and 9 stations in Arab Peninsula. The results showed that CFSR dataset have a good agreement with most of Egyptian stations and North West Africa Stations, However, the correlation was found smaller in Arabian Peninsula. They expressed that CFSR dataset can be used as a good substitute for the lack of the solar ground observation over the whole MENA region except Arabian Peninsula which can be used but with less quality [12]. 
Not only number of observation stations to record solar radiation is sparse and unevenly distributed but also, there is no information about the accuracy of satellite-based solar radiation data in Turkey. General objective of the study is to examine accuracy of freely available CFSR solar radiation data against ground observation data based on monthly averages over the Hatay province in Turkey.

\section{Materials and Methods}

This study carried out in Hatay province in Turkey, Hatay has a total land area about 5403 square kilometers and located between $35^{\circ} 52^{\prime}$ to $37^{\circ} 40^{\prime}$ 'north $35^{\circ} 40^{\prime}$ to $36^{\circ} 35^{\prime}$ East. Hatay's climate is semiarid characterized by hot and dry in summer, warm and rainy in winter. While ground-based solar radiation observations provide accurate measurements that are generally spatially unevenly distributed in Hatay province, satellite-based estimations offer spatially and temporarily regular observations. Twelve stations which have long time solar radiation record were chosen in Hatay. Position of study area is shown in Figure 1 and position of ground stations are shown in Figure 2 CSFR dataset downloaded from internet in the 30.11.2017. (http://globalweather.tamu.edu/data/cfsr/65272). Position of CFSR gridded data set is shown in Figure 3

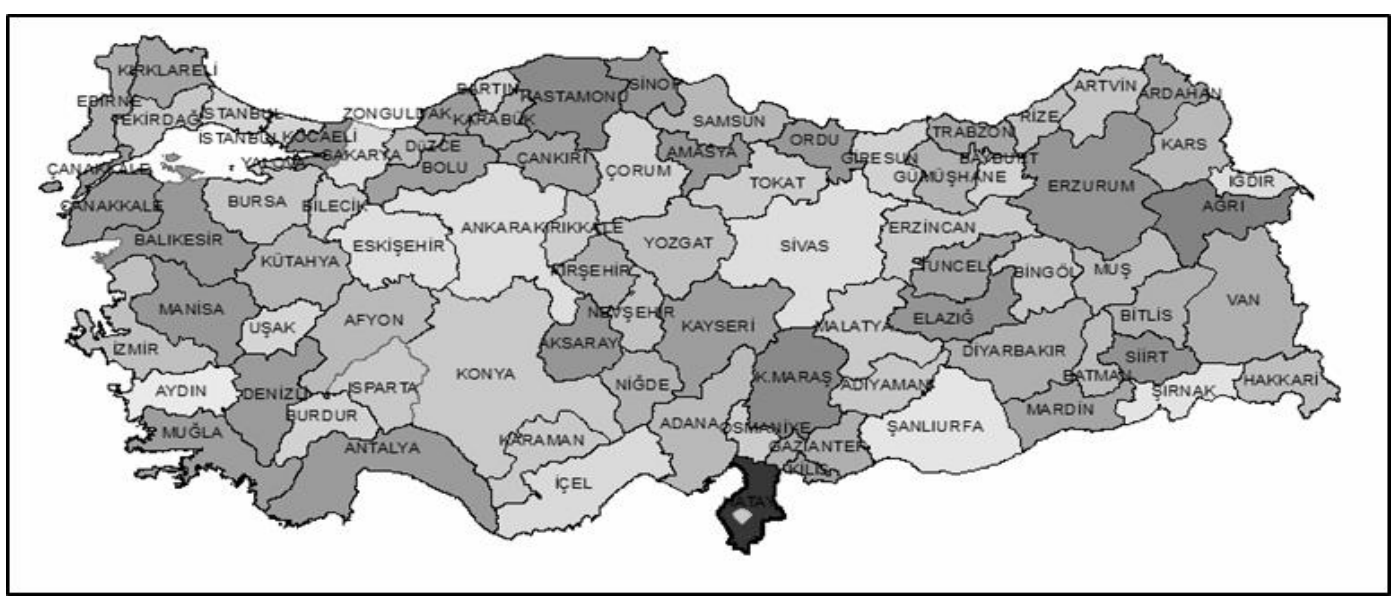

Figure 1. Position of study area

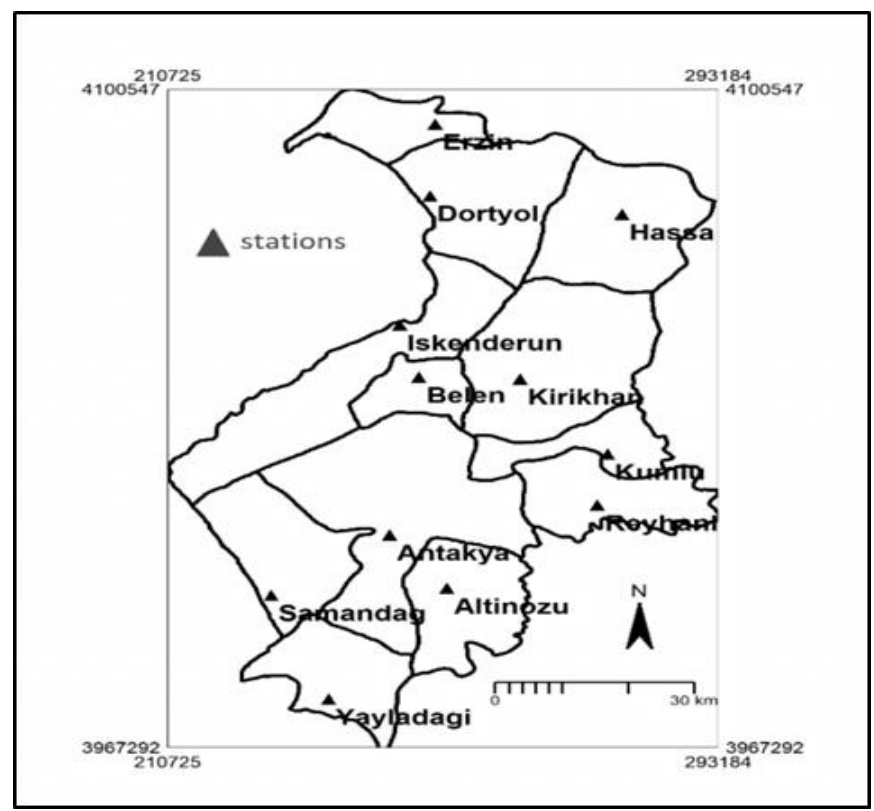

Figure 2. Position of ground stations 


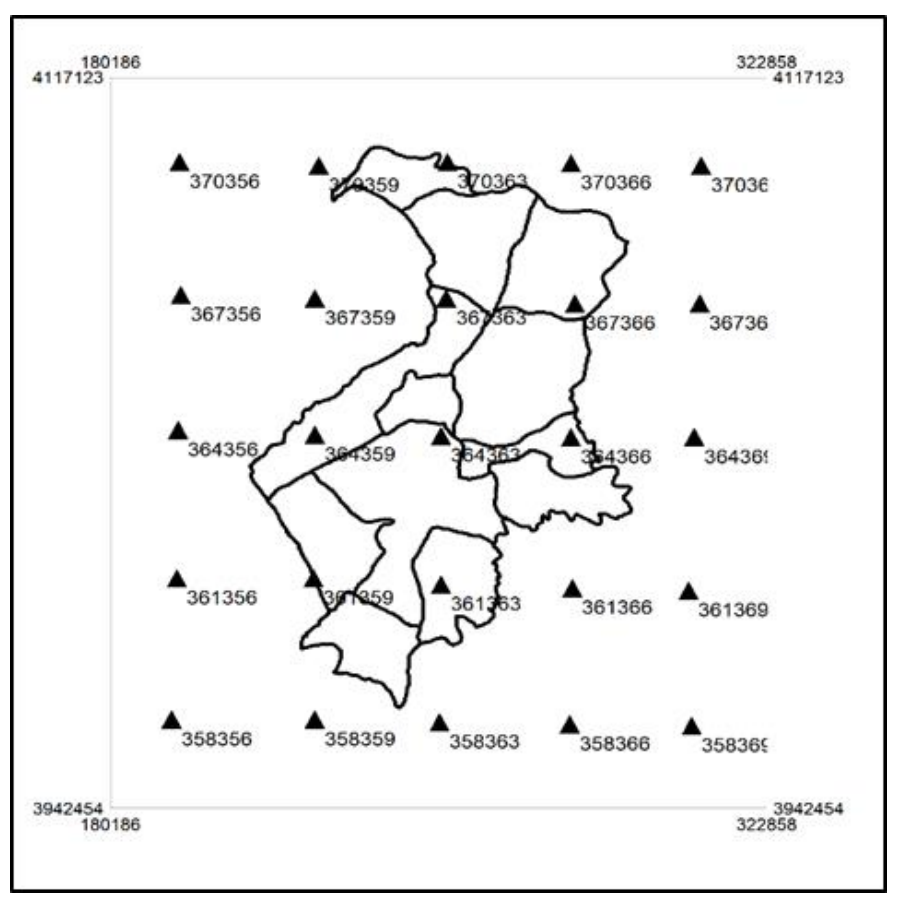

Figure 3. Position of CFSR data

In this study, satellite-based dataset from National Center for Environmental Prediction (NCEP) Climate Forecast System Reanalysis (CFSR) was used. Ground-based data was obtained from Global Energy Potential Atlas of Turkey (GEPA, 2018). GEPA has 500x500 m gridded average annual and monthly solar radiation map. Also, it has average monthly solar radiation for area within each counties borders were given in Figure 4 and monthly averaged solar radiation values were given for Iskenderun county in Figure 5.

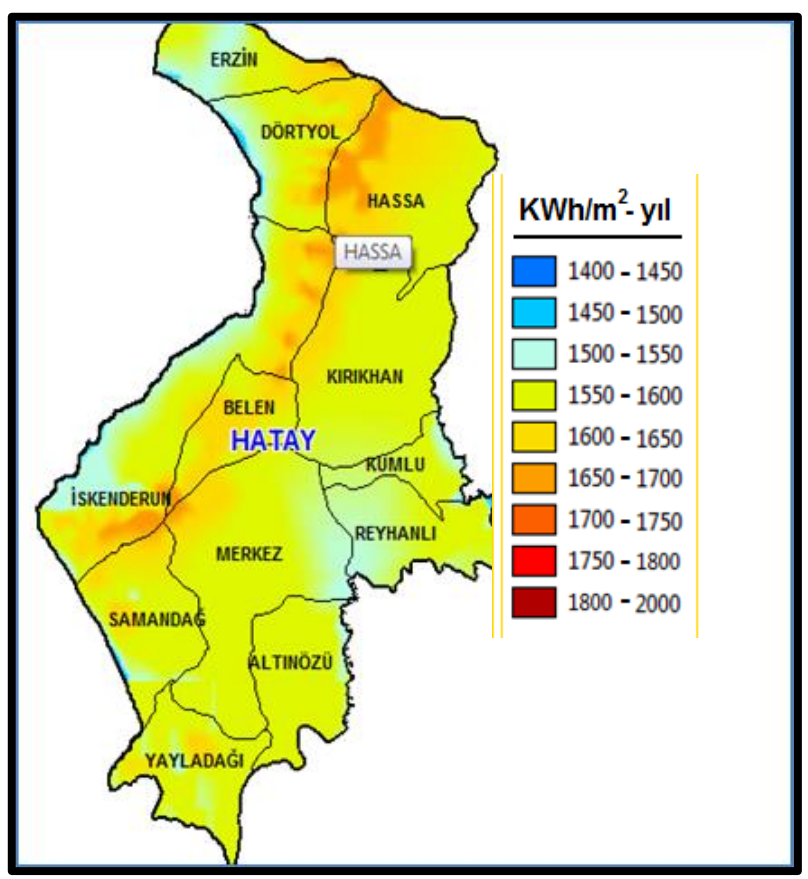

Figure 4. Ground-based observation data [13] 


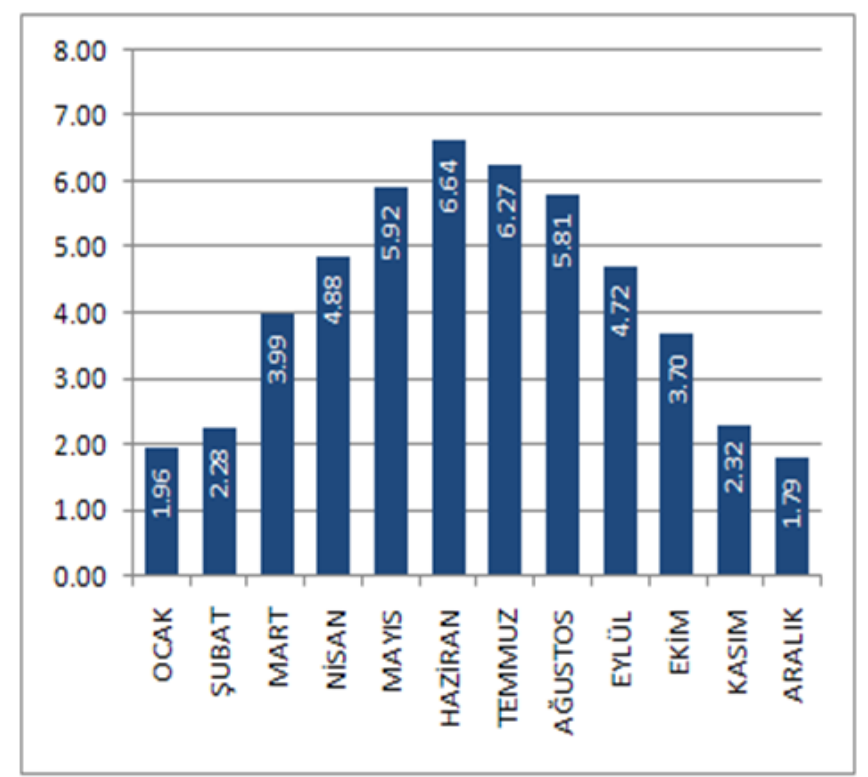

Figure 5. Monthly Averaged solar radiation values for Iskenderun county [14]

Both location of satellite estimation points and ground observation points have been transferred to ILWIS GIS software using coordinate information of points. Average monthly solar radiation for each point calculated from daily solar radiation values for the same point. Average monthly solar radiation values assigned to each point to generate solar radiation point map. IDW point interpolation method was used to generate spatial distribution of solar radiation over the study area.

Three statistical measures were used to compare CFSR data with GEPA data consisting of coefficient of determination $\left(\mathrm{R}^{2}\right)$, Root Mean Square Error (RMSE) and Mean Bias (MB). Correlation coefficient $\left(\mathrm{R}^{2}\right)$ between CSFR and GEPA was calculated by using Equation 1.

$$
R^{2}=\left(\frac{n \sum\left(G_{i} S_{i}\right)-\left(\sum G_{i}\right)\left(\sum S_{i}\right)}{\sqrt{\left(n\left(\sum G_{i}^{2}\right)-\left(\sum G_{i}\right)^{2}\right)\left(n\left(S_{i}^{2}\right)-\left(\sum S_{i}\right)^{2}\right)}}\right)^{2}
$$

where, $\mathrm{R}^{2}$ is the coefficient of determination, $\mathrm{Gi}$ is Ground-based measurements, $\mathrm{Si}$ is Satellitebased estimates, and $\mathrm{n}$ the number of data pairs.

Root Mean Square Error (RMSE) measures the difference between distributions of Satellite and ground base solar radiation data. It is calculated using Equation 2.

$$
R M S E=\sqrt{\frac{\sum\left(G_{i}-S_{i}\right)^{2}}{n}}
$$

where, RMSE is Root Mean Square Error, Gi is Ground-based measurements, Si is Satellitebased estimates, and $\mathrm{n}$ the number of data pairs.

Bias (BIAS) is simply ratio of the mean of Satellite based solar radiation estimation value to the mean of the ground-based observed value. It is calculated using Equation 3.

$$
B I A S=\frac{\sum S_{i}}{\sum G_{i}}
$$

where, Gi is Ground-based measurements and $\mathrm{Si}$ is Satellite-based estimates. 


\section{Results and Discussions}

The CFSR dataset including 25 daily solar radiation measurement points was evaluated against 12 ground stations for 21-year period (1985 - 2006). The unit of CSFR data ( $\mathrm{MJ} \mathrm{m}^{-2}$ ) was converted to observation data unit $\left(\mathrm{kWh} \mathrm{m}^{-2}\right)$. Each solar data value assigned to location of measurement and estimated points. Generated point maps for CFSR and ground stations for April are shown in Figure 6 and Figure 7, respectively.

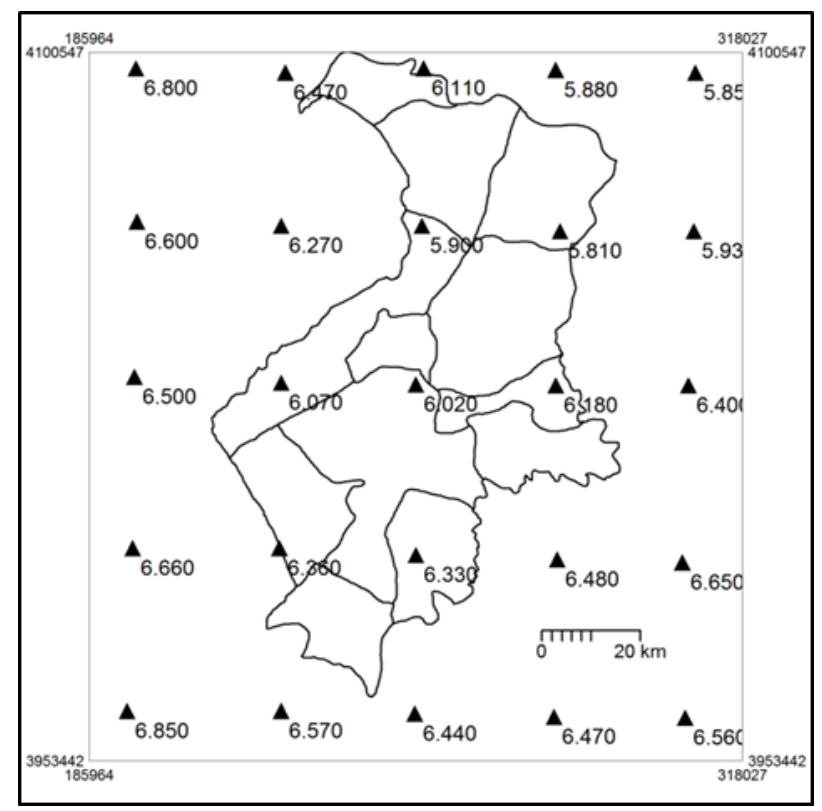

Figure 6. Point values for April (CSFR)

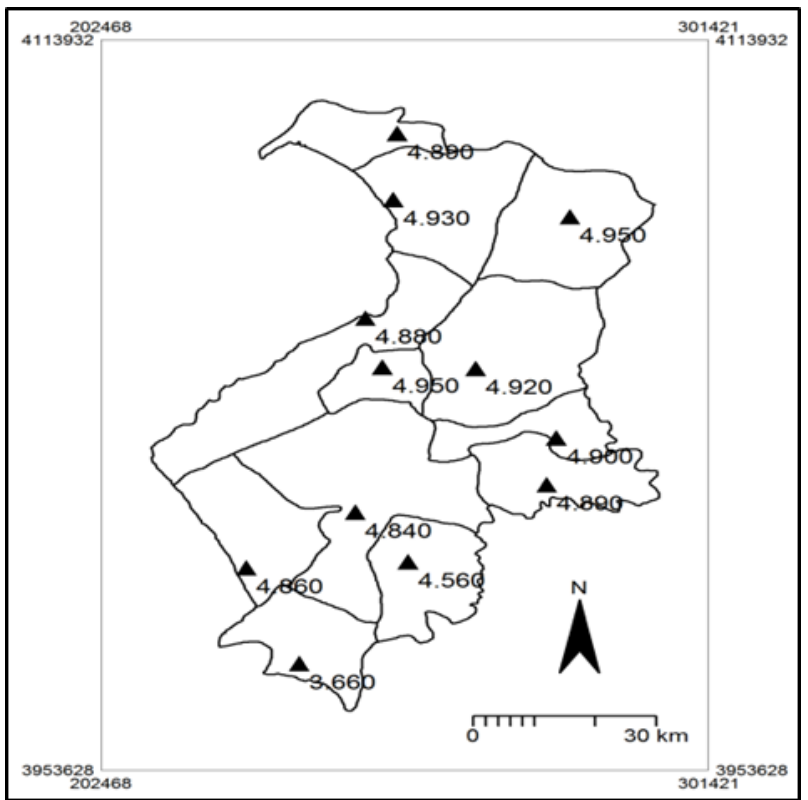

Figure 7. Point values for April (Stations)

IDW point interpolation method was used to generate spatial distribution of solar radiation over the study area. Spatial distributions of CSFR values and station values for April are shown in Figure 8 and Figure 9, respectively. Areal weighted station values and CSFR values within the border of counties calculated based on monthly averaged using histogram calculation operation within ILWIS. Histogram calculation results were given for Iskenderun in Figure 10. 


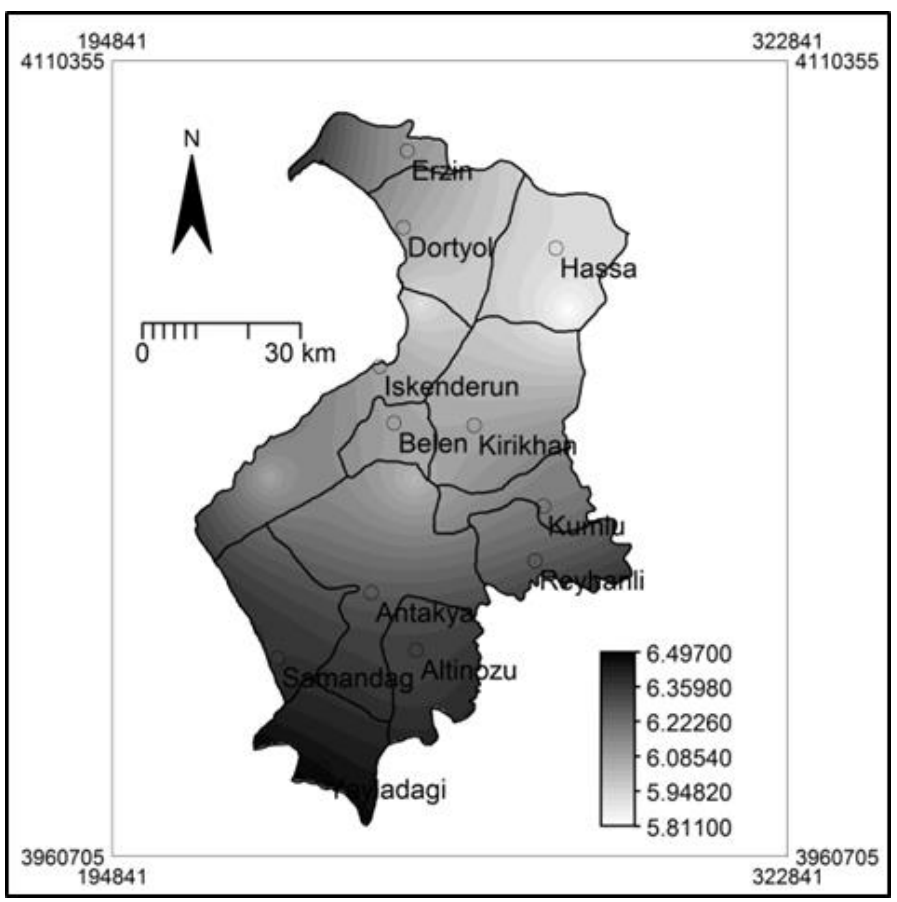

Figure 8. Raster map for April (CFSR)

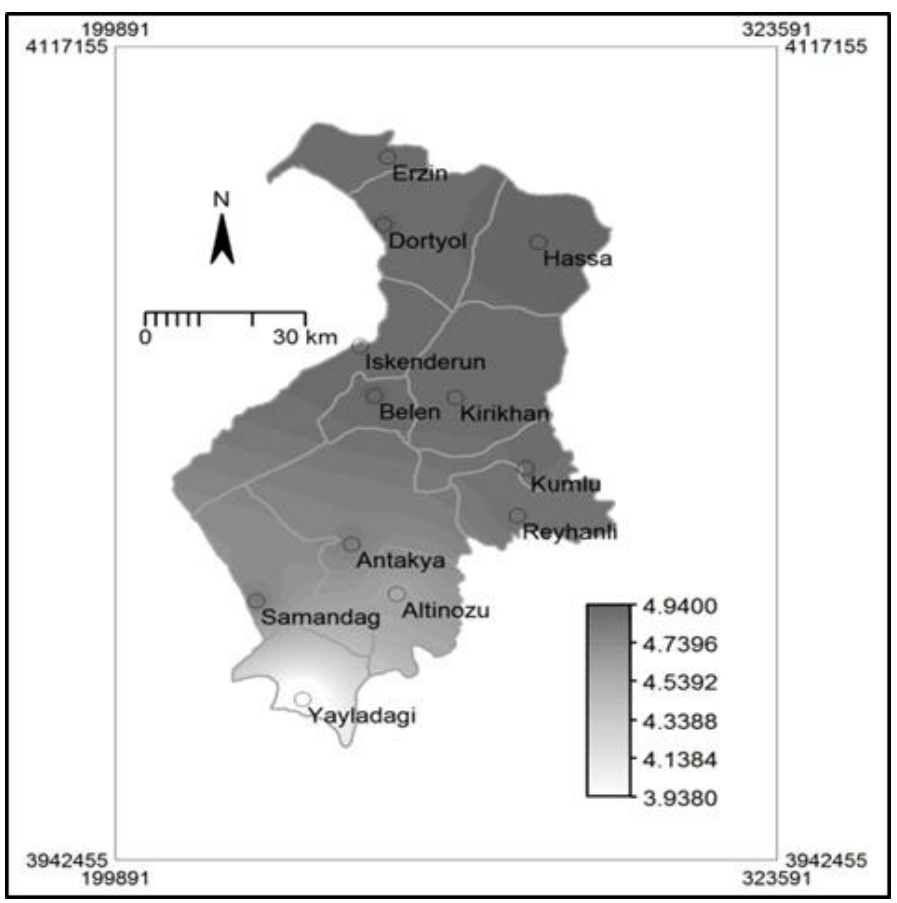

Figure 9. Raster map for April (Stations)

Three statistical measurements were used to evaluation of CFSR data sources. The RMSE, Bias and Correlation coefficient $\left(\mathrm{R}^{2}\right)$ between the stations and the solar radiation data derived from the CFSR dataset are presented in Table 1 . 


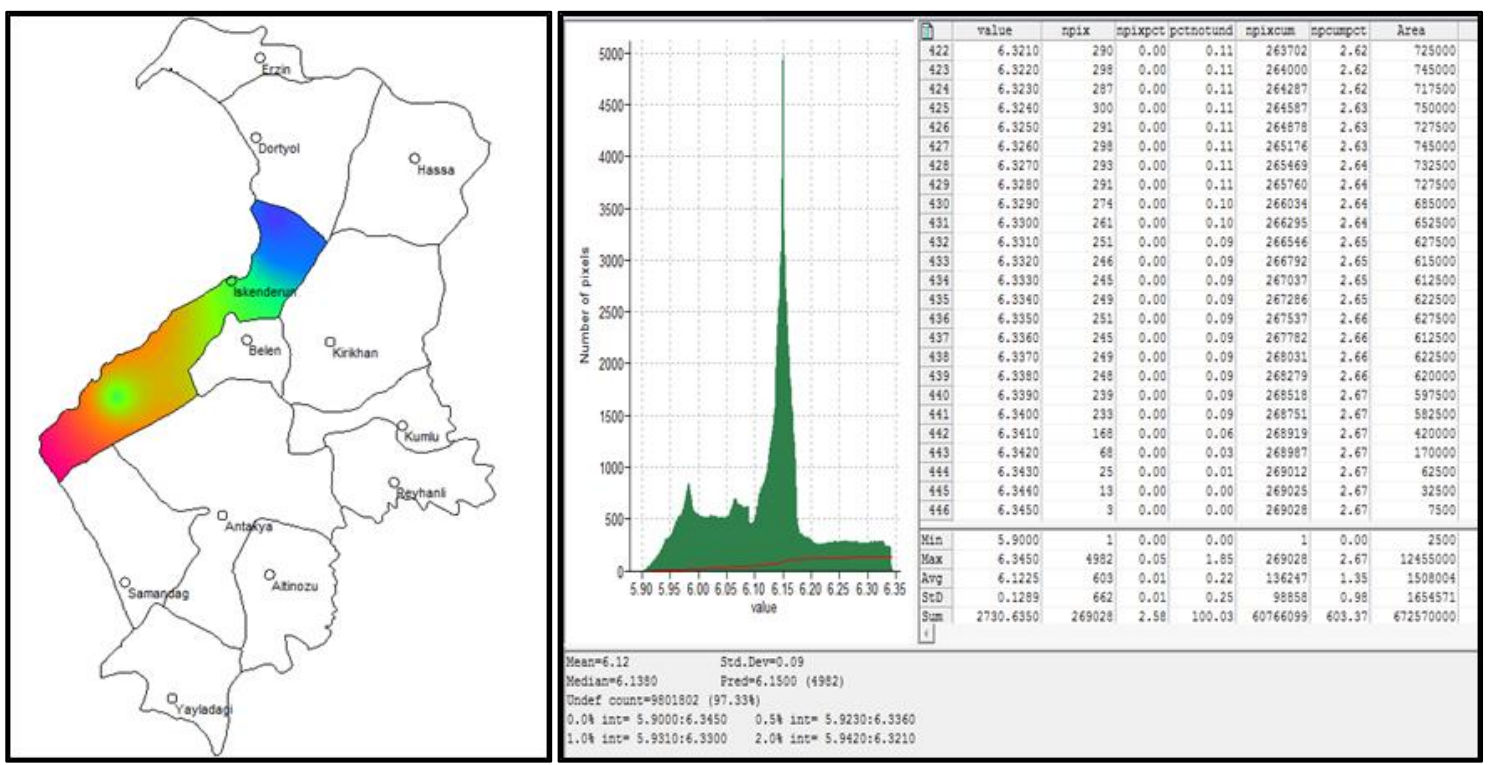

Figure 10. Histogram results for Iskenderun

Tablo 1. Statistical results of study

\begin{tabular}{lllllllllllll}
\hline & JAN & FEB & MAR & APR & MAY & JUN & JUL & AUG & SEP & OCT & NOV & DEC \\
\hline $\mathbf{R}^{\mathbf{2}}$ & 0.63 & 0.15 & 0.19 & 0.64 & 0.29 & 0.16 & 0.07 & 0.02 & 0.65 & 0.73 & 0.55 & 0.66 \\
RMSE & 0.36 & 0.85 & 0.77 & 1.45 & 1.56 & 1.89 & 2.03 & 1.73 & 1.57 & 0.95 & 0.66 & 0.36 \\
Bias & 1.17 & 1.35 & 1.19 & 1.29 & 1.26 & 1.29 & 1.32 & 1.30 & 1.33 & 1.26 & 1.28 & 1.19 \\
\hline
\end{tabular}

\section{Conclusions}

Statistical results showed that most correlations in monthly basis data were weakly correlated. Moderate positive correlation was found 0.63, 0.64, 0.65, 0.55, 0.66 for January, April, September, November, December, respectively. High positive linear association between two dataset found only for October $\left(\mathrm{R}^{2}=0.73\right)$. Negligible correlation under 0.30 was found for February, March, May, June, July and August. According to results of Bias, CFSR monthly averaged solar radiation was over estimated for all months. Monthly averaged satellite-based solar radiation estimation is range between $\% 17$ and $\% 19$ higher than the average ground based solar radiation for January, March and December. It is highest (\% 35 ) in February. other months ranged between $\% 26$ and $\% 30$.

The results show that the use of the CFSR dataset is not advisable in the absence of annual and monthly average ground-based solar radiation measurement values. Estimated CFSR data has need to be improved and accuracy of CFSR data must be tested for other regions in Turkey. We recommend finding another source of satellite-based data to compare with ground-based data.

\section{References}

[1] Worqlul A.W., Maathuis B., Adem A.A., Demissie S.S., Langan S., Steenhuis T.S. 2014. Comparison of Rainfall Estimations by TRMM 3B42, MPEG and CFSR with Ground-Observed Data for The Lake Tana Basin in Ethiopia. Hydrology and Earth System Sciences, 18: 4871-4888. doi: 10.5194/hess-18-4871-2014.

[2] Lekula M., Lubczynskia M.W., Shemangb E.M., Verhoefa W. 2018. Validation of Satellite-Based Rainfall in Kalahari. Physics and Chemistry of the Earth, 105: 84-97. doi: 10.1016/j.pce.2018.02.010.

[3] Sharp E., Dodds P., Barrett M., Spataru C. 2015. Evaluating the Accuracy of CFSR Reanalysis Hourly Wind Speed Forecasts for the UK, Using in Situ Measurements and Geographical Information. Renewable Energy, 77: 527-538. doi: 10.1016/j.renene.2014.12.025. 
[4] Xue Y., Huang B., Hu Z.Z., Kumar A., Wen C., Behringer S., Nadiga S. 2011. An Assessment of Oceanic Variability in The NCEP Climate Forecast System Reanalysis. Climate Dynamics, 37 (1112): 2511-2539. doi: 10.1007/s00382-010-0954-4.

[5] Wang W., Xie P., Yoo S.H., Xue Y., Kumar A., Wu X. 2011. An Assessment of The Surface Climate in The NCEP Climate Forecast System Reanalysis. Climate Dynamics, 37 (7-8): 16011620. doi:10.1007/s00382-010-0935-7.

[6] Chelliah M., Ebisuzaki W., Weaver S., Kumar A. 2011. Evaluating the Tropospheric Variability in National Centers for Environmental Prediction's Climate Forecast System Reanalysis. Journal of Geophysical Research, 116: D17107. doi:10.1029/2011JD015707.

[7] Higgins R.W., Kousky V.E., Silva V.B.S., Becker E., Xie P. 2010. Intercomparison of Daily Precipitation Statistics Over the United States in Observations and in NCEP Reanalysis Products. Journal of Climate, 23: 4637-4650. doi:10.1175/2010JCLI3638.1.

[8] Mo K.C., Long L.N., Xia Y., Yang S.K., Schemm J.E., Ek M. 2011. Drought Indices Based on the Climate Forecast System Reanalysis and Ensemble NLDAS. Journal of Hydrometeorology, 12: 181-205. doi:10.1175/2010JHM1310.1.

[9] Li D., Christakos G., Ding X., Wu J. 2018. Adequacy of TRMM Satellite Rainfall Data in Driving the SWAT Modeling of Tiaoxi Catchment (Taihu Lake Basin, China). Journal of Hydrology, 556: 1139-1152. doi: 10.1016/j.jhydrol.2017.01.006.

[10] El Afandi G. 2014. Evaluation of NCEP Climate Forecast System Reanalysis (CFSR) Against Surface Observations Over Egypt. American Journal of Science and Technology, 1(4): 157-167.

[11] Malvern S.F., Maurice C. 2018. Comparison of Satellite Data and Ground Based Weather Data in Masvingo, Zimbabwe. International Journal of Environmental Sciences \& Natural Resources, 8 (4):555739. doi:10.19080/IJESNR.2018.08.555739.

[12] Khaled W.M., El Afandi G. 2014. Evaluation of NCEP/CFSR Solar Data Against Ground Observation Over MENA. Open Journal of Atmospheric and Climate Change,1-12.

[13] GEPA. 2018. Güneş enerjisi potansiyeli atlasi verileri. http://www.yegm.gov.tr/MyCalculator/Default.aspx (Erişim Tarihi: 03.02.2018).

[14] GEPA. 2018. Güneş enerjisi potansiyeli atlas1 verileri. http://www.yegm.gov.tr/MyCalculator/pages/31.aspx (Erişim Tarihi: 03.02.2018). 